\title{
Promoting Respect as a Human Value in a Public School
}

\author{
Josefina Quintero Corzo ${ }^{1} \&$ Yeisson Soto Castañeda ${ }^{2}$ \\ ${ }^{1}$ Department of Education, Universidad de Caldas, Manizales, Colombia \\ ${ }^{2}$ Modern Languages Licenciatura Programe, Universidad de Caldas, Manizales, Colombia \\ Correspondence: Josefina Quintero, Department of Education, Universidad de Caldas, Manizales, Calle \\ 65-26-10, Colombia. Tel: 57-968-781-513. E-mail: josefina.quintero@ucaldas.edu.co
}

Received: July 22, $2017 \quad$ Accepted: August 25, $2017 \quad$ Online Published: November 28, 2017

doi:10.5539/ies.v10n12p96 URL: https://doi.org/10.5539/ies.v10n12p96

This research is financed by Universidad de Caldas, Colombia

\begin{abstract}
This is a case study report arising from a series of daily observations of the students' behavior made in a primary public school located near to the capital city, Manizales -Colombia, where it was possible to notice the difficulties students had in order to coexist due to the lack of respect with their classmates, in group activities or actually working in pairs throughout the foreign language class. The aim of this investigative project was to counteract the daily levels of aggressiveness presented by the students among themselves, to promote good teamwork and respect as an important issue in a good coexistence. Based on the observed settings, the results revealed that it was possible to highlight the necessity of learning to live together and to enhance the value of respect for others creating new ways of working in terms of coexistence. Promoting human values in the classroom brought profit for children and was fundamental in primary school from their earliest ages, due to the school must play a leading role in the construction of integral citizens, for a better society. Some of the activities, contents and games after being applied such as bingo, lotteries, word searches, puzzles, animal behavior and others, generated a connection between meaningful language learning, good teamwork and human relations. These classroom strategies became new alternatives for a teacher training program that claimed for immediate and demanding solutions to improve children's character development inside public schools.
\end{abstract}

Keywords: coexistence, foreign language, human values, public school, respect, teacher training programs

\section{Introduction}

\subsection{Education, Human Rights, and Teaching Language Trends}

Through the passing of ages, the Latin American countries have lived a series of social and ideological movements aimed to confirm the identity of the different communities recognizing the value of their cultural, ethnic, linguistic, ecological and social legacy. These countries have built a historical memory with many differences and similarities in relation to their own roots, because of the mixture among Native American, Spaniards and other foreign influences (Soto, 2005). Although the majority of them speak the Spanish tongue since the beginning of the XVI century, it is noticeable a linguistic diversity of the indigenous groups (Usma, 2009).

Education is an inalienable and fundamental statement acknowledged as a universal human right which has been translated into juridical or legal instruments of international public rights included on the constitutional principles and values, so that it is possible to construct a more just society. Therefore, several international organizations and different literature review like Boff (2008), Munévar-Quintero and Giraldo-Quintero (2015), the Political Chart (1991), Soto-Arango (2005), the United Nations Educational, Scientific and Cultural Organization [UNESCO] and Food Agriculture Organization of the United Nations [FAO] (2003), UNESCO (2001) UNESCO (2014) and UNESCO (2015) confirm a strong oppression, illiteracy, malnutrition risks, environmental damage, infringement of the human rights and a low quality of the education systems. These studies advocate that education should be focused on harmony and peace with nature and between peoples. At the same time, they claim for new policies responses offering equal opportunities to all individuals.

Nonetheless, at the moment of analyzing the accomplishment of the millennium objectives proposed in the 
Education for All Program and in the Regional Educational Project for Latin American and the Caribbean (UNESCO, 2001; UNESCO, 2014), the quality of the education evidences current challenges which have to be covered like: equity, coexistence, tolerance, and peace. As the above mentioned issues have set out, there is a discouraging situation due to the dissatisfaction of the basic, individual and collective needs of the population.

Historically, in Colombia, peripheral public schools receive students from the rural sectors and neighborhoods far from the urban perimeter that have the highest illiteracy rate, fewer schools, less health services and job opportunities. They have little academic support from their families because their parents work at home and other field occupations, away from libraries and poor access to internet, low level of education and disintegrated families, where the mother is head family. Their salary is low and feeding habits are deficient. Children must work after the school day and walk long distances to get to school. Inequality of opportunities compared with the private sector also affects the schooling population.

This way, the aims of education cannot be reduced to preserving the interrelations between the individuals, its context and its immediate culture, but must also inculcate values that allow the coexistence of peoples belonging to different contexts, including different societies and cultures.

Becoming a new educator in real contexts such as it is described above, means a high quality and complex profession. It implies the direct design and development of the systematic processes about teaching, learning and assessment, and other functions inside the framework of the Institutional Educational Project (IEP). Beyond the development of lessons, the teacher' academic assignment also includes the improvement of curricular activities, the student orientation service, the attention to the family expanded to the academic community, the continuous updating of renewing pedagogical trends, institution policies management, planning, and evaluation strategies. Furthermore, other cultural and sport events contemplated in the IEP are also included in the long list of the teachers' accountabilities.

Concerning the students' behavior and coexistence, Colombian educators play an important role in this difficult responsibility because they become models, examples and for some children, teachers can even be considered their heroes. Then, pre-service and in-service teachers must totally understand and appropriate fundamental values, so that children can learn such good manners, attitudes and respect habits from themselves.

According with the Colombian education policies, the Ministry of Education (Law 115/1994), universities devote much of its efforts to prepare new generations of teachers able to improve the quality of education, as well as encourage values and moral principles. It is for each of these reasons that most schools adopt the humanist approach, inspired by powerful emotions, national symbols representing idealistic desires, nature care, freedom, peace and coexistence.

One of the most recent curriculum reforms at the university level, probes for endowing a new educator with scientific, ethical and pedagogical competences identifying them as reflective and transformative professionals. An innovative strategy consists of linking the gap between research process and teaching skills on the part of those students who decided to become educators, taking into account that classrooms' reality has to turn its pedagogical practices in order to apply the most effective research trends. According to the university regulations, it is mandatory and necessary to do research processes as a requirement to obtain the graduate title in the teacher education programs. That is why the teaching practicum is the last year curriculum stage where the teacher trainees (it means new teachers or pre-service teachers) are located in a public or private educational institution.

Concerning the language teaching and learning process, it is necessary to introduce research competences in order to transform traditional and outdated practices, as well as overcome severe difficulties. Updated studies in the country (Fandiño, 2013; Macías \& Sánchez, 2015; MEN, 1999; MEN, 2006; McNulty \& Usma, 2005; Ramírez, 2008; Usma, 2009) have found that the English classroom is extremely focused on the teacher who decides what to do, when and how to do it, the activities are repetitive and isolated, evaluation is mechanical and irrelevant, skills are not related nor integrated, poor opportunity of communication, lack of autonomy due to the student's passive role, and so on.

Nowadays, in a society with cultural mobility, the role of foreign languages should be a primordial tool to construct a world's representation, to build knowledge, and to reach a full social, cultural, scientific, and technological integration among peoples. Apart from stimulating to great educators, Colombian education policies (1999) have devoted much of its efforts to reinforce those curriculum subjects that are very useful for the development of meaningful teaching and proper learning implemented by both public and private institutions.

Specifically, the Universidad de Caldas located in the Colombian Coffee Region, has institutionalized research 
lines as an indicator of high quality accreditation according to the social mission and goals established in its Development Plan (2009-2018). The most relevant for this project is the action-research line centered on strategies and methods for teaching and learning foreign languages. English is one of the basic and most important curriculum subjects to be taught and learnt in the Colombian education system (Law 115, 1994), along with Spanish, Nature Sciences, Maths, Social Studies, Technology, Sports, Arts and Humanities, among others.

\subsection{The Institutional Setting}

The setting of this case study work is a peripheral public school located just in the Coffee Region which is a country zone dedicated to the collection of coffee, farming and livestock. Although it is a rural school, placed in areas remote from urban populations, is just 10 minutes from Manizales downtown. The metropolitan municipality reaches a population close to 557,060 habitants according to the official demographic projections for the year 2017. Of its cultural activity Manizales is very recognized for its regional fairs, national and international theater festivals, artistic events, and the most important musical genres ever heard along the history of Colombia stand out here. This municipality is the so-called "City of Open Doors" thanks to the cordiality of its people.

The beautiful Coffee Region is situated between the western center of Colombia and the Central Mountain Range of the Andes. The history of this region is perhaps one of the best examples of recent national industry's push and storage of agricultural production which means a large economic presence for the country. It is one of the most visited landscapes for tourists from everywhere, both Colombians and foreigners. It is also very recognized as a gastronomic place where people use to come on weekends to try typical food. The region is surrounded by mighty rivers, marvellous snow mountains and a variety of climates. Due to these geographic, ecologic, historical and cultural characteristics, the coffee landscape was declared a World Heritage Site by UNESCO in 2011.

\subsection{The Problem Area}

When a new teacher arrives to a classroom, the first idea spread in his/her mind is that it will be a great class played in a comfortable place, different from all others. In fact, when working with children, he/she must handle a conceptual order and prepare creative instructional materials. In addition, he/she must use a simple language to communicate with students, so that they can understand. Nevertheless, how could a new foreign language teacher react to a situation of aggression in the classroom? Or what if in the middle of the class topic, an episode of this type is presented? For many people it is a very difficult situation, authorities and experts do not even know what to do, so the main idea of this work is to learn how to handle affairs like this in the English classroom.

In his diary, the teacher trainee wrote:

At the beginning of the school year, everything seemed like a game. The students met again after their vacations, they played and had fun as they used to, but with the passing of days, reality began to become a little dark. A chain of games and activities of friendship began to get deteriorated by screams, fights and blows. As a trainee teacher in English subject, I started to worry and at the same time I started to do two things: First, I began to make an analysis about the students' behavior in class and out of class, with or without their parents and with or without their partners. Secondly, I began to think about how I could solve this problem, considering that I am their English teacher, a naïve teacher.

As time went by, the teacher trainee was analyzing the attitude of the students, and came to the conclusion that it was necessary to talk more of human values than masterful grammar. So, he began to integrate English subjects with principles and values of the human being. Of course, he was not going to leave the English language aside, but rather he looked for the way to integrate two of the most important things that can have the human being: knowledge and to live in community.

In his diary, the teacher trainee wrote once again:

Faced with a disruptive behavior such as this, which my students had, especially those in the second and fifth grades, I asked myself what was wrong and where this behavior came from. I assumed that a person receives his first formation at home. However for a beginning English teacher like me, it was very difficult to go to each of my students' house to see how they live or how they behave at their homes. That was impossible! But what I could do (very discreet and respectfully) was to talk to them, and let them tell me things like: why did they like to come to school? What did they like to learn? Who came to pick them up? And, who took them home again? Who did they live with? Who helped them with their tasks? Etc.

Sincerely, the teacher trainee was surprised with some students' answers like these: "teacher, really, nobody picks 
me up and my parents do not even help me with my tasks". "Teacher, I come here because I like to play with my friends and no more". "I stay alone at home and my parents do not look at my notebooks nor help me".

That's why the teacher trainee realized that some children needed significant support from their parents throughout their learning process. He also noticed that children who their parents took them to the school, who checked their notebooks and homework, and those who received more care and attention, were the most studious children in class. Unfortunately, after having done this analysis and diagnosis, it was evident that the children, who needed this support from their family, were also the most undisciplined, rude and hyperactive. It is supremely important that a child be properly accompanied by their parents in both personal and academic processes. Schools and families must be able to correct students' problems of behavior that may later become problems of social violence and aggression.

After analyzing the institutional context, and also the role of parents and new teachers in the process of learning, a series of questions such as, are posed: Why do some children find it so difficult to work as a team? Why do some of them prefer to be alone? Why do they sometimes physically and verbally attack?

Although some of the children present problems of isolation and aggressiveness, there are others who play an excellent role as students. It means that they have a proper accompaniment from their parents and maybe, this fact facilitates learning and allows the development of students' emotions and affections. Contrary to those students whose parents do not even check their notebooks to look at their homework. The teacher trainee wrote in his diary:

I am afraid. If we talk about the reality we live today, not only in the streets (which are full of evil and danger) but also in some public institutions, the value of respect and healthy coexistence have been lost in a scandalous way.

Below, there is a complementary list of the attitudes of daily aggressiveness and lack of coexistence observed by the teacher trainee and written down in his diary:

-Children of second grade do not integrate among themselves

-I organize pairs to perform an activity and a second child says: "No, I do not work with her, "I just don't want to"

-A fifth grader passes and throws a ball to another classmate hurting his face

-Pass a second grade child and without reason hits one of his classmates on the head

-A third grade girl lets fall a pencil, a fifth grade passes and throws it away

-A third-grader shouted me

-Second grade children try to put pressure on the teacher at the same time because he does not let them go to the bathroom together

-A third grade child passes and pulls a partner's hair.

\subsection{Research Question}

How can the value of respect be promoted inside the foreign language classroom as a curriculum subject in a public school?

\subsection{Objectives}

-To promote the value of respect as the basis of human coexistence during the teaching and learning process of English as a curriculum subject in a primary public school.

-To counteract the daily levels of aggressiveness presented by the students among themselves as necessary in a good coexistence

-To innovate in a way of team work in terms of coexistence and respect towards the others.

-To create a pleasant atmosphere simultaneously with the integral, personal and academic formation in children at the school.

\section{Method}

\subsection{Case study}

This case study project was developed in a public education institution where a language teacher trainee from the Universidad de Caldas in Manizales -Colombia, carried out his teaching practicum as a requirement of graduation. Researchers such as Angrosino (1989), Creswell (1998), Nunan (1997), Stake (1995), Wallace (1998) 
and Yin (1984) have probed that case study is an empirical enquiry carefully planned and crafted that produces relevant evidence leading to understand in depth a real life situation of a small number of events, individuals or problems. This research method is useful to prepare new educators identifying them as reflective and transformative professionals. It also offers contributions to link the gap between human inquiry and teaching skills on the part of those who decided to become educators, taking into account that classrooms' reality has to turn its traditional practices into the most effective trends (Schön, 1983; Schön, 1987).

\subsection{Participants}

The case study process took place in a peripheral public education institution and was made by a foreign languages trainee teacher and his assessor. The average number of elementary students, girls and boys, attending the English classes (first, second, third, fourth and fifth grade respectively) was sixty-two, and their ages were between seven (7) and thirteen (13) years old. Bearing in mind that it is a public school, most of the students do not have enough resources, even many of them come to school walking.

\subsection{Data Collection, Instruments and Analysis}

To collect as much data as possible, guided by the initial research question concerning the lack of respect in the English classroom, several tools served as means of accompaniment during the analytical process. Records, diary entries, observations, notes, and workshops were the tools used in gathering the information needed. The purpose of the diary was to record each one of the experiences lived in class and to take notes about students' behavior, development and progress. Besides, many of the school's visual and physical materials were accessible to work with children at the time of the classes. The school was provided with work aids such as flashcards, books, lassos, booklets, board games, posters, video beams, television sets and some other primers from which work materials were extracted for the proper class approach.

Once information was available, the analysis was carried out, considering what the students produced on their own and what was intended to achieve "a better coexistence among students and teamwork development", so it was observed if the value of respect promoted in the English classes was yielding satisfactory results.

\subsection{Action Stage}

This stage consists on preparing a set of classroom activities aimed at generating a connection between meaningful language learning and human values, such as: respect, honesty, love for others, the importance of teamwork and friendship. Fifteen (15) English classes were oriented by the teacher trainee, who played the role of a new teacher at a public school, following the curriculum standards established by the National Ministry of Education and adopted by the IEP through the syllabus. Some strategies, contents and games such as bingo, lotteries, word searches, puzzles, animal behavior and others, were planned and applied during the first academic period, from January to June in 2017. For the purpose of this article, a sample of five (5) activities was selected and presented below.

\subsubsection{The Phrase of the Week}

First of all, to promote the use of principles and values of the human being the teacher trainee decided to use a strategy called 'the phrase of the week', which consists of working in each class a sentence focused on a specific value, with the intention of allowing a better coexistence. Some of the phrases worked throughout the classroom research project were:

-Respect is necessary for a good coexistence

-I love my classmates and I like to work with them

-Together we will do it!

-We are all different and we must respect those differences

-I must raise my hand to speak

-If I do not know the answer, my partner can help me

-The school is for everyone, so I will take care of it

-In my school I educate myself but also I form myself as a human being

-Dialogue helps me to solve problems

-I should not argue, on the contrary I must share with my classmates and be humble. 


\subsubsection{Activity Number One. Greetings and Farewells. "Knowing My Friends"}

Linguistic objective: to work on the different conjugations of verbs and the use of pronouns through greetings and farewells.

Communicative objective: to develop in children the ability to greet and say goodbye in a formal and informal way through oral and written activities.

Warm up: Every student is going to stand up and say hello to everybody. It does not matter if he/she does not have a close friendship with them. On the contrary, this exercise promotes the creation of friendship.

Development: The group was divided into small groups. Each one proposes a global simulation which shows to meet a friend again, after a long time of absence. After that we are going to socialize together.

Evidence: the following pictures show an example of the students' work made in class, using conjugations of verbs and pronouns through greetings and farewells.

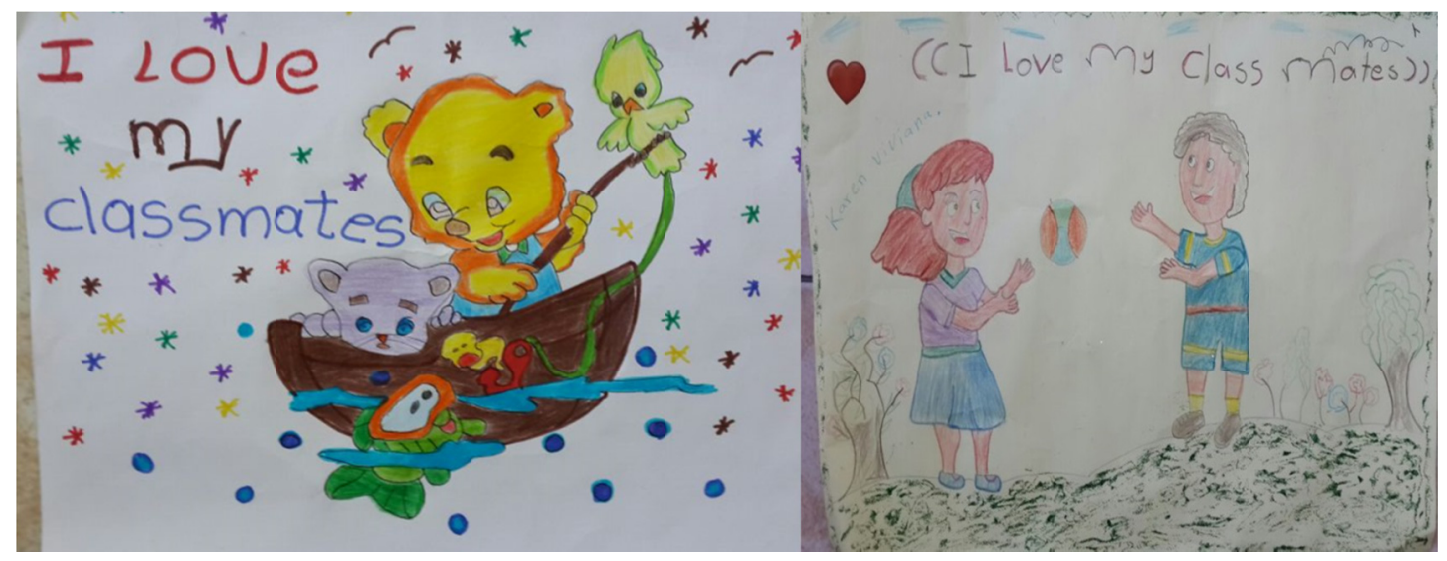

\subsubsection{Activity Number Two. Places at School. "Having Care of Our Second Home"}

Linguistic objective: to understand the vocabulary corresponding to each one of the parts or places at school, in the moment of hearing them in conversations or seeing them in written texts.

Communicative objective: to create in children the ability to say the different names of places at school, not only in Spanish but in English too.

Warm up: students are going out and they are going to describe the school. They will take notes about the resources and rooms that the school has.

Development: once students recognize the most important places of the school, teacher trainee introduces: "the school as our second home", with the purpose of teaching them how important it is, that we all live in it, we learn in it and that we must have care of it, and have care and help our classmates. Later, students work a series of principles and human values that are fundamental for a good coexistence. Although it is important to know how to live together and live in communion, these values must be practiced lifelong.

Evidence: the following pictures show an example of the students' work made in class, using vocabulary about to each one of the parts or places at school. 


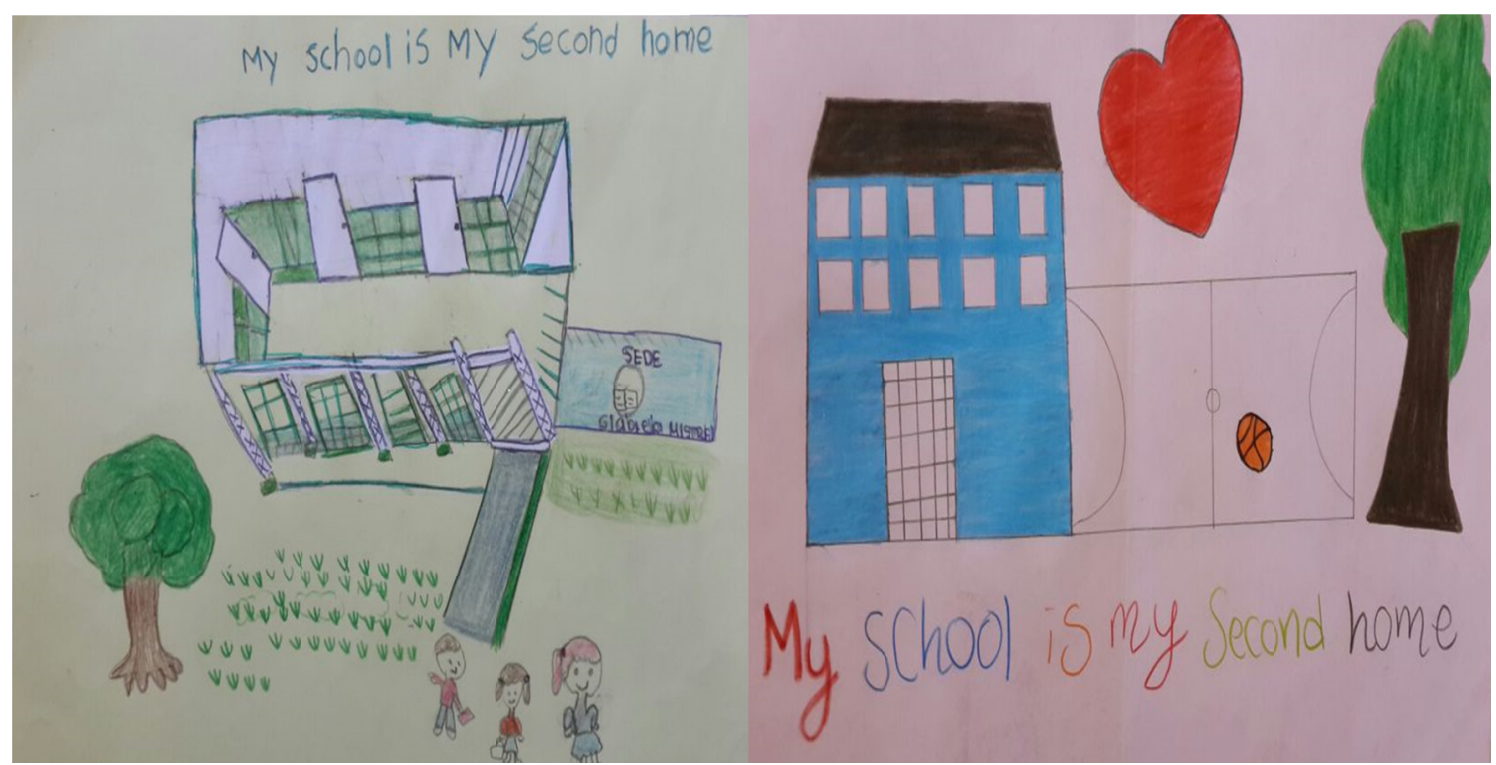

2.4.4 Activity Number Three. Our Body. "Each Person Is a Different Individual and We Must Respect That"

Linguistic objective: to identify each one of the parts or the body and through repetition acquire the knowledge of them in student's conversations.

Communicative objective: to develop in children the ability to use parts of the body in English in their daily talks.

Warm up: each one is going to stand up and teacher trainee says a part of the body aloud, but he certainly touches another part of the body. Students should follow the order given orally and not the order made with gestures.

Development: Each student is going to choose a partner and will say what he / she likes about him or her and why he admires him / her. After this, teacher trainee proceeds to teach them the parts of the body in English, emphasizing that our body is very valuable and that we must take care of it. In addition, highlighting the fact that each part of the body is different and fulfills a different function, but very important, just like humans, we are all different but deserve respect and equality.

Evidence: the following picture shows an example of the students' work made in class, identifying the parts or the body and expressing that each individual must respect that. 


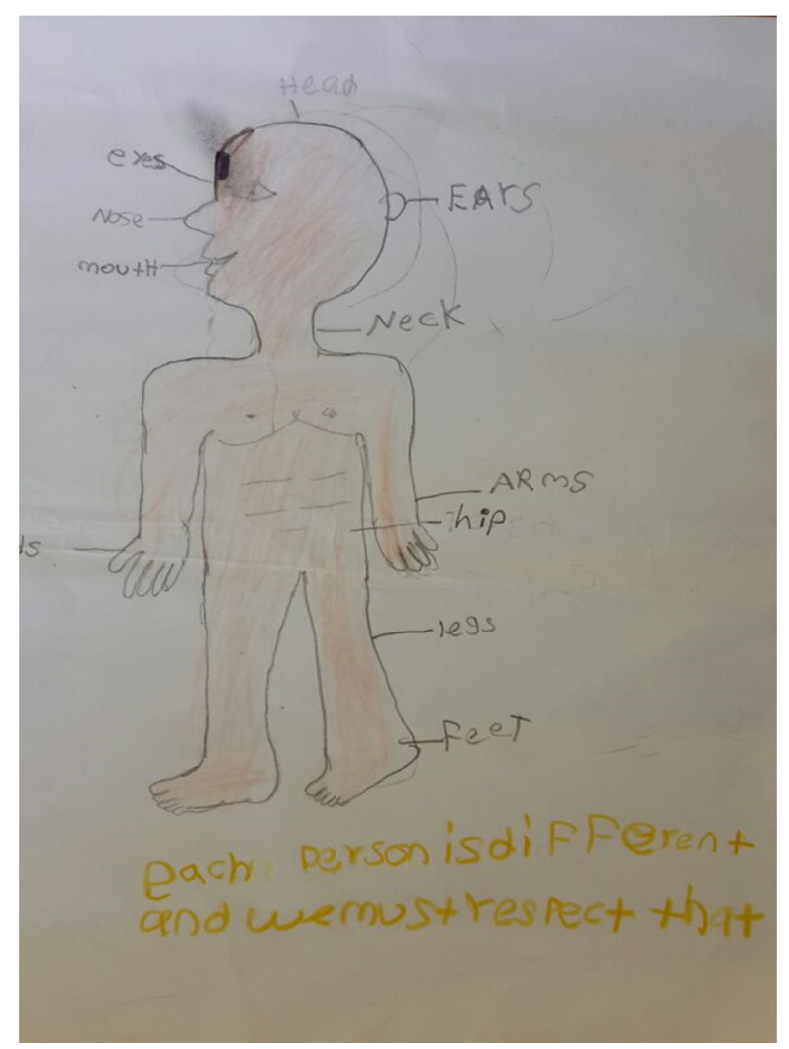

2.4.5 Activity Number Four. Days of the Week/Months of the Year. "A Wonderful Year Sharing With My Classmates, From Monday to Friday"

Linguistic objective: to identify each one of the different days of the week and months of the year, recognizing them in texts, books and listening activities.

Communicative objective: to encourage in children the use of days of the week and months of the year in English in their daily conversations.

Warm up: at the beginning, the activity consists on looking at an almanac and saying what day and date your birthday is, so that other students can write down these dates and they can congratulate each classmate in his / her birthday.

Development: To teach the days of the week and the months of the year in English, letting the students know how important it is to come to the school and how important their classmates are, as they are the people they see from Monday to Friday at the school. Therefore it is important to maintain a good coexistence.

Evidence: the following pictures show an example of the students' work made in class, recognizing the different days of the week and months of the year. 


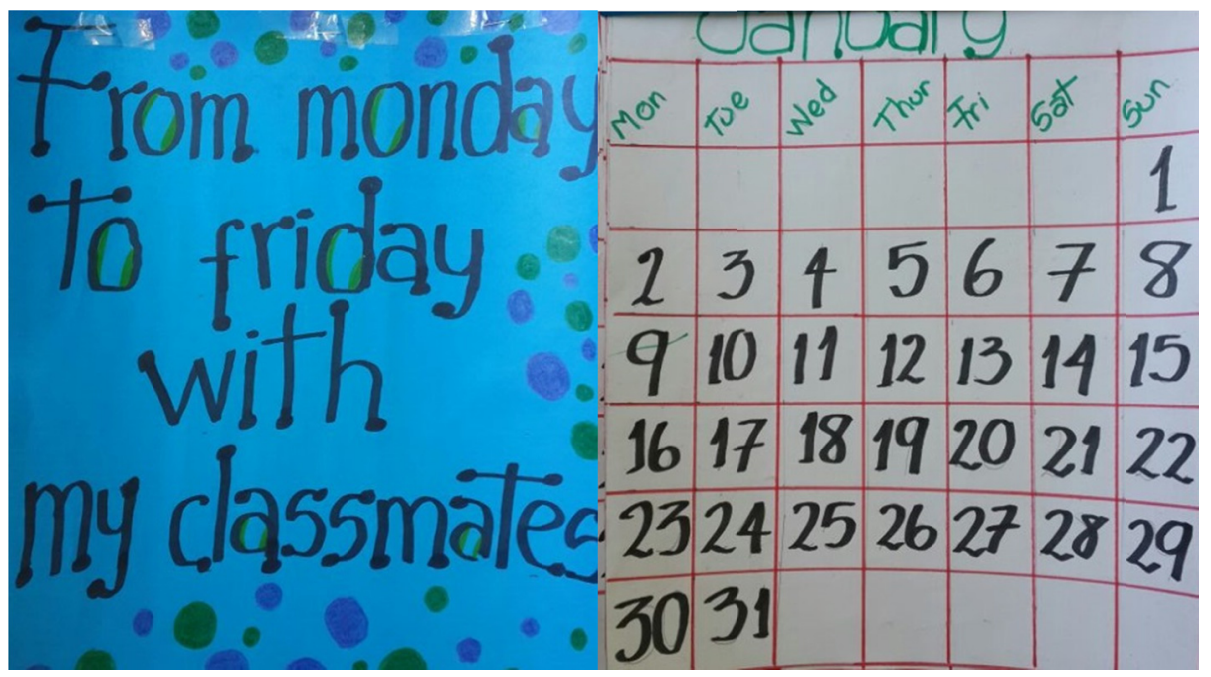

2.4.6 Activity Number Five. The Animals: An Excellent Example of Teamwork, Respect and Solidarity

Linguistic objective: to recognize the vocabulary related with the best known animals and those of their family environment.

Communicative objective: to motivate students to use English when they see an animal in their environment.

Warm up: Organize a round table. Each student will say the name of an animal and the student, who can remember the largest number of animal names, will be the winner.

Development: teacher trainee introduces the subject by working separately on earth animals, water animals and birds. It was very significant to take into account the way of life that animals have, even serving as an example to humans in terms of coexistence, teamwork, responsibility, intelligence, respect and solidarity.

Evidence: the following pictures show an example of the students' work made in class, related with the best known animals in their surrounded environment.

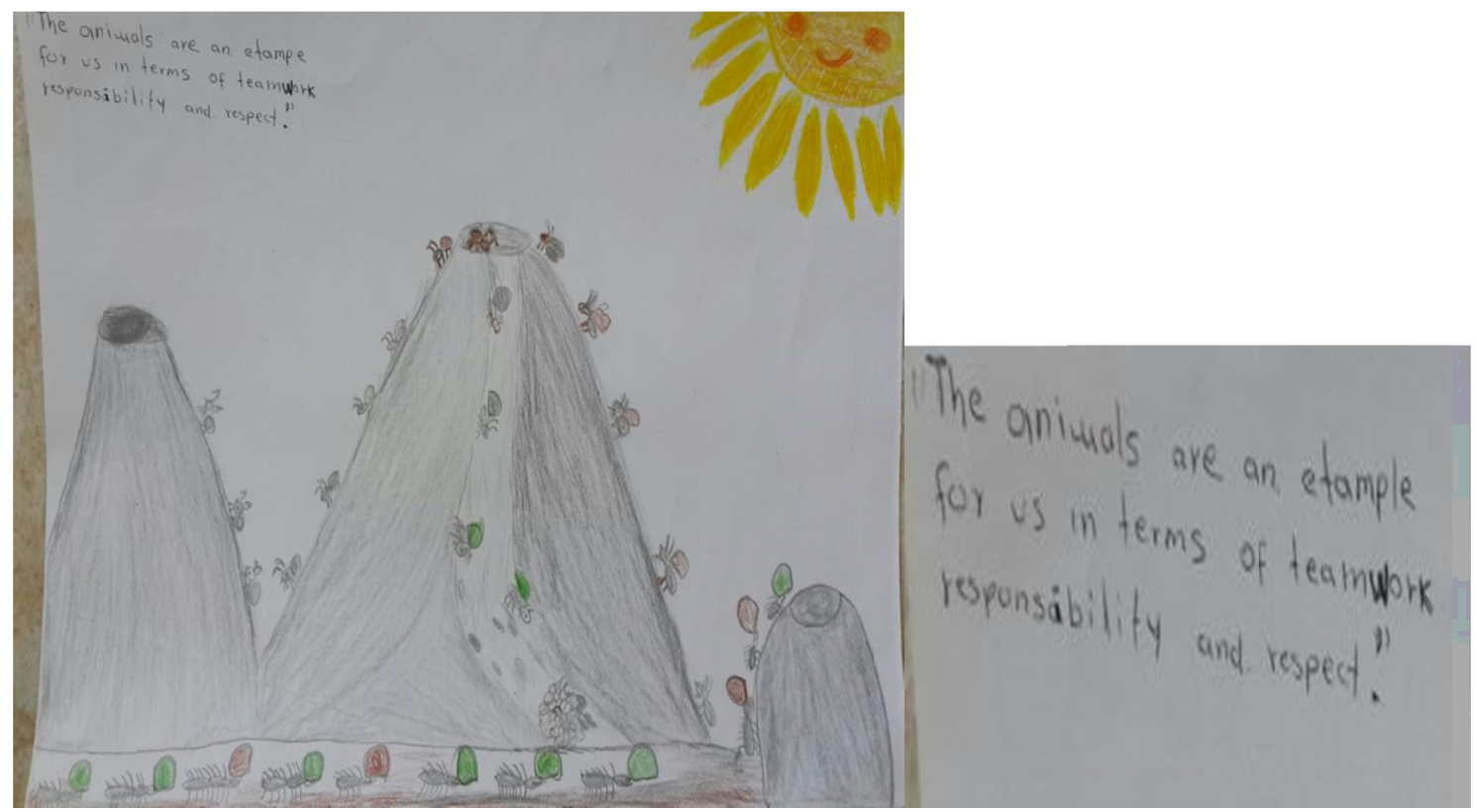

\subsection{Evaluation}

In the first instance, teacher trainee had to use an elementary level of English, introduced by simple and contextual sentences and commands, in as much as public school has not been enough contact with the language and that causes the process to be carried out slowly in terms of the language. Secondly, he had to focus on how 
important it is to respect and be respected, since this human value works as a motor in a good coexistence. Therefore as a new teacher, he tried to be an example to his students respecting them always, both in class, and out of class. And thirdly, he served as a monitor for his students, so that if they had any kind of questions concerning or not with the classes, they could consult him, and he did this with the intention of generating an atmosphere of trust, friendship and collaborative work, so that they can observe the importance of helping others and a good teamwork.

Likewise, observations and self-observations were made jointly with the Principal, the school teachers, the university advisor and the trainee teacher, allowing to analyze the weaknesses and strengths manifested throughout this project and from which it was possible to probe that the objectives are fulfilled as the project was executed.

It was crucial to emphasize on the importance of oral activities conducted in class that involve students, but simultaneously make them conscious of the meaning of respect for their classmates. These activities were: debates, questions and answers in groups, weekly phrases with a specific message, group sentences, role plays, animal behavior, etc. Finally, it is necessary to highlight the importance of the pedagogical diary, which has been keeping through the whole classroom research process.

\section{Results}

Through the integration of human principles and values in the English classroom, the following results obtained are highlighted:

Through the class activities, workshops and oral exercises, it was evident that children used words and expressions such as "please, thank you, you're welcome..." whenever they needed something. Likewise, attitudes of respect increased when they communicate ideas or during different interaction events inside and outside the classroom. An atmosphere of cordiality and a due treatment in class at the end of the semester was different from those episodes observed at the very beginning.

One of the most satisfactory accomplished objectives was the apprehension of rules related with teamwork. This was a notorious aspect throughout the project allowing them to form integrated working groups not only by students of the same course, but also of different grades.

The frequent development of joint activities (which aim was to generate a collective integration among the students of the school, inculcating values such as affection, empathy, friendship, joy and a healthy coexistence), allowed them to generate a better teamwork. At the moment students were working in teams, it was possible to observe that this work was unanimous and collaborative, so that each one of the members of the group participated in the proposed activities. Students understood the thematic contents and there was a higher participation expressing interest and good manners.

Thus, the project called "Promoting Respect as a Human Value in a Public School" yielded the expected results in support of the desired goal and the initial research question. The majority of teachers of the institution expressed to remark a change in the attitude of children in terms of coexistence and teamwork, allowing them to understand the importance of promoting human values in the personal and integral development from early ages.

Finally, the teacher trainee wrote in his diary:

From my appreciative point of view as a trainee teacher, I have to say that the change experienced in the attitude of my primary students at the school has been significant and more than rewarding, making me learn from a wonderful experience and likewise making me feel more than proud of the results obtained throughout this last semester of my career.

In order to achieve the results, as a trainee teacher I had to take into account several aspects, which I had to analyze and modify in order to allow the project to develop correctly and to have these results.

The diary has been a wonderful and very important experience, so as a teacher trainee, I advise the use of the pedagogical diary in the teaching and training processes. For which, we can use important tools as the pedagogical diary and gliders.

\section{Discussion}

This classroom case study discusses how the so-called school is a space of social and cultural relationship where the citizen in training process should be guaranteed the normal development and enjoyment of fundamental rights (Boff, 2008, Munévar-Quintero \& Giraldo-Quintero, 2015; UNESCO, 2015). However, the educational institution has been blamed for problems of violence, terrorism, punishment, juvenile delinquency, wrongdoing, lack of values and all the ills that afflict the current society. Same way, according to Boff (2008), today's society 
requires new pathways and constant care in order to counteract the increasing devastations of nature resources affecting the humankind such as poverty, exclusion and lack of spiritual values. Nonetheless, authors such as Collins (2017, p. 1) found out that the value of 'Respect' has been adopted as a new concept added to 'Courage, Initiative and Teamwork' in an army or military context. This work presents a training model to instill such a value as respect. The results also endorse Martínez-Scott, Monjas-Aguado and Torrego-Egido's argument (2017) in teachers training, supporting the social mission of universities to underpin attitudes and moral values, including justice, solidarity and respect.

Many occasions, both pre-service and in-service teachers do not discern how to deal with the different situations that can be presented in the classroom, so, it is necessary to record each of the events experienced in these classrooms. As teacher trainees, a diagnosis about the possible problems of coexistence that can be presented in classrooms and based on that look for different and possible solutions is urgent and necessary. What they must do as new teachers is to show their students that the classroom is a space to learn and to train as a human being and not to foment violence.

According to new pedagogical models specially the active learning and the humanistic approach (Colbert, 2006; Gregory, Clawson, Davis \& Gerewitz, 2016; Ramírez, 2008), students can be oriented to work as a team. It is also possible to develop a sense of shared authority or ownership on the part of teachers because the aim is to promote a pleasant classroom atmosphere based on healthy coexistence and human values. Gregory et al. (2016) add that as students interact about one another, they are able to exchange opinions, accept feelings, identify causes and consequences, prepare action plans to restore damages and prevent future conflicts among groups.

The spiritual value of respect is maybe one of the most imperative actions to be promoted at school daily life, because it is the base of human relationships and allows a good coexistence between groups. It matches the thesis supported by Martínez-Scott et al. (2017) warning on the "defense and promotion of all people's human rights" as an indicator of development education.

It is not possible to talk of respect at school without talking about others. Respect is a form of recognition and appreciation of the qualities and differences of others. It is essential because that exemplifies the act by which human beings have consideration for another bearing in mind their interests, abilities, preferences, fears or feelings. No doubt, respect is one of the most important and primary actions that students can have among themselves and that let them know that each classmate is different in order to live in a better community. It is necessary to establish limits of manners and habits of what the whole academic community can and cannot do and where others' limits start.

The integration of principles and values in conjunction with the learning process is an approach that all teachers should put into practice, because it should not simply be about generating content learning, but perfect human formation that is the starting point of a good coexistence. Thus, human beings become integral and trained, both professionally and humanly, so that they can develop without any problem in the world of today. As the teacher trainee stated in his diary, exercising the value of respect inside the English classroom allows both society and families to live in peace, in a healthy coexistence based on norms and institutional regulations:

By the above, I refer to the advances manifested in terms of coexistence in the classroom, but at the same time, the problems and impasses that can be presented, which are used as information to develop our work strategies.

\section{Conclusions}

The first idea that can be concluded is that this has been an empirical enquiry case study useful for both students and teacher trainees who need relevant evidence leading to a deeper understanding of misbehavior of students in the English class. Results allowed to realize that different activities can be organized in an orderly way to achieve particular objectives concerning the value of respect.

It is important to highlight the fact that the objectives were achieved, since the students, have been involved with a series of principles and fundamental values for the coexistence as human beings. Students have changed some of the attitudes that appeared at the beginning of the process, concluding that the promotion of values and principles brings positive consequences to favor healthy coexistence inside the classroom.

It is also concluded that the participants in this case study worked too much in teams, when previously it caused them many difficulties to interact with their classmates due to the series of differences that existed among them. Although some differences persist, the coexistence in the group has improved and the foreign languages classes worked according to the established plan.

It is important to foreground that nowadays more importance is given to values as part of the school mission. So 
that, it is necessary and possible to motivate future citizens leaving behind isolated curriculum topics and rescuing the role of the teacher. The project fulfills this purpose, highlighting the importance of aspects such as: teamwork, respect for peers and learning to live together in a social environment, and as it was said before, serving as an example to future generations.

Finally, it is very gratifying to observe that the relationships among students have evolved in a notable way. Teacher trainee has changed the complaints, problems and discussions, for sharing among the school members, for enjoying a healthy environment and for a better coexistence, which was the purpose of this project.

This finished classroom case study takes strength and validity to carry out, becoming an effective teaching and learning experience, and bringing relevant evidence to improve real life situations and problems at a public school.

Mission accomplished!

\section{Acknowledgments}

To the research group called Innov-Acción Educativa, which has maintained the highest categories in the national ladder. This group also counts with enough trajectories to continue with the lines supported by interesting issues found around the educational community aimed at preparing a better teacher for a better country.

To educational institutions, both basic and higher level such as "Gabriel Mistral" and Universidad de Caldas in Manizales, Colombia, through the Department of Educational Studies in charge of preparing the most outstanding generation of educators in the Coffee Region.

To the Vendimia Group from Universidad Pedagógica y Tecnológica de Colombia in Tunja, on behalf of Dr. Diana Soto Arango who supports the development of high quality doctoral and post-doctoral research projects.

\section{References}

Angrosino, M. V. (1989). Documents of interaction: Biography, autobiography, and life history in social science perspective. Gainesville: University of Florida Press.

Boff, L. (2008). Essential Care: An Ethics of Human Nature. Waco, Texas, United States: Baylor University Press. Retrieved from https://www.amazon.com/Essential-Care-Ethics-Human-Nature/dp/1602581428

Colbert, V. (2006). Mejorar la calidad de la educación en escuelas de escasos recursos. El caso de la Escuela Nueva en Colombia. Revista Colombiana de Educación, 51, 186-212. Universidad Pedagógica Nacional Bogotá, Colombia. Retrieved from http://www.redalyc.org/pdf/4136/413635245008.pdf

Collins, P. (2017). The value of respect: what does it mean for an Army? Journal of Military Ethics, 16(1), 1-18. https://doi.org/10.1080/15027570.2017.1337712

Colombia, Ministerio de Educación Nacional-MEN. (1994). La Reforma Educativa; Ley General de Educación (Ley 115). Bogotá: Ediciones Fecode. Retrieved from http://www.mineducacion.gov.co/1621/articles-85906 _archivo_pdf.pdf

Colombia, Ministerio de Educación Nacional. (1999). Idiomas extranjeros: Lineamientos curriculares, áreas obligatorias y fundamentales. Bogotá: Ediciones MEN. Retrieved from http://www.mineducacion.gov.co/ cvn/1665/articles-89869_archivo_pdf4.pdf

Colombia. (1991). Constitución Política. Retrieved from http://www.cna.gov.co/cont/documentos/legislacion/ constitucion.pdf

Colombia. Ministerio de Educación Nacional-MEN. (2006). Estándares básicos de competencias en lengua extranjera: inglés. Formar en lenguas extranjeras: El reto. Retrieved from http://www.colombiaaprende.edu.co/html/mediateca/1607/articles-115375_archivo.pdf

Creswell, J. W. (1998). Qualitative inquiry and research design. Thousand Oaks, CA; London: Sage.

Fandiño, Y. (2013). Knowledge base and EFL teacher education programs: a Colombian perspective. Íkala, revista de lenguaje y cultura, 18(1), 83-95.

Gregory, A., Clawson, K., Davis, A., \& Gerewitz, G. (2016). The Promise of Restorative Practices to Transform Teacher-Student Relationships and Achieve Equity in School Discipline. Journal of Educational and Psychological Consultation, 324-353. https://doi.org/10.1080/10474412.2014.929950

Macías, D. F., \& Sánchez, J. A. (2015). Classroom management: A persistent challenge for pre-service foreign language teachers. PROFILE Issues in Teachers' Professional Development, 17(2), 81-99. 
Martínez-Scott, S., Monjas-Aguado, R., \& Torrego-Egido, L. (2017). Hunger and prejudice. A study of development education in teachers training. Proccedia Social and Behavioral Sciences, 237, 950-955. Universidad de Valladolid, Plaza de la Universidad 1, Segovia, Spain. Retrieved from http://www.sciencedirect.com

McNulty, M., \& Usma, J. (2005). Evaluating research skills development in a Colombian undergraduate foreign language teaching program. Íkala, 16, 95-125. Medellín: Editorial Escuela de Idiomas de la Universidad de Antioquia.

Munévar-Quintero, C. A., \& Giraldo-Quintero, R. (2015). Desarrollo y derechos humanos: Incidencias, aproximaciones y tendencias. Revista Jurídicas, 12(1), 25-42.

Nunan, D. (1997). Research methods in Language Learning. United Kingdom: Cambridge University Press.

Ramírez, O. (2008). The English Language Learning inside the Escuela Activa Urbana Model in a Public School: A Study of Sixth Graders. PROFILE, 9(1), 47-62.

Schön, D. (1983). The Reflective Practitioner: How professionals think in action. London: Temple Smith. Basic Books, Inc.

Schön, D. (1987). Educating the Reflective Practitioner: Toward a New Design for Teaching and Learning in the Professions. San Francisco California: Jossey-Bass Inc., Publishers.

Soto-Arango, D. E. (2005). Aproximación histórica a la universidad colombiana. Revista Historia de la educación latinoamericana-RHELA, 7, 101-138. Tunja. Universidad Pedagógica y Tecnológica de Colombia. RUDECOLOMBIA.

Stake, R. (1995). The art of case study research. Thousand Oaks, CA: Sage.

UNESCO. (2014). Latin American and the Caribbean. Education for All 2015 Regional Review. Santiago-Chile. OREALC/2014/PI/H/1. Retrieved from http://unesdoc.unesco.org/images/0023/002327/232701e.pdf

UNESCO. (2015). Education 2030: Incheon Declaration and Framework for Action. Towards inclusive and equitable quality education and lifelong learning for all (Final draft for adoption). Paris. Retrieved from http://www.unesco.org/new/fileadmin/MULTIMEDIA/HQ/ED/ED_new/pdf/FFA-ENG-27Oct15.pdf

United Nations Educational, Scientific and Cultural Organization [UNESCO]. (2001). Pathways into the Third Millennium: Society, Knowledge and Know-How. Report. Naples, Italy. Retrieved from http://unesdoc.unesco.org/images/0012/001256/125670e.pdf

United Nations Educational, Scientific and Cultural Organization [UNESCO] \& Food and Agriculture Organization of the United Nations [FAO]. (2003). Education for rural development: towards new policy responses. Retrieved from http://unesdoc.unesco.org/images/0013/001329/132994e.pdf

Universidad de Caldas. Plan de Desarrollo (2009-2018). "Para el desarrollo de la región y el avance de la ciencia $y \quad$ la cultura". Manizales. $\quad$ Retrieved from http://www.ucaldas.edu.co/foroPDI/PDI/docs/PLANDEDESARROLLO2009-2018UCALDAS.pdf

Usma, J. (2009). Education and Language Policy in Colombia: Exploring Processes of Inclusion, Exclusion, and Stratification in Times of Global Reform. PROFILE, 11(1), 123-141. Retrieved from http://www.scielo.org.co/scielo.php?script=sci_arttext\&pid=S1657-07902009000100009\&lng=en\&nrm=iso \&tlng=en

Wallace, M. J. (1998). Action Research for Language Teachers. Teacher Training and Development. Cambridge: Cambridge University Press.

Yin, R. K. (1984). Case study research: Design and methods. Newbury Park, CA: Sage.

\section{Copyrights}

Copyright for this article is retained by the author(s), with first publication rights granted to the journal.

This is an open-access article distributed under the terms and conditions of the Creative Commons Attribution license (http://creativecommons.org/licenses/by/4.0/). 